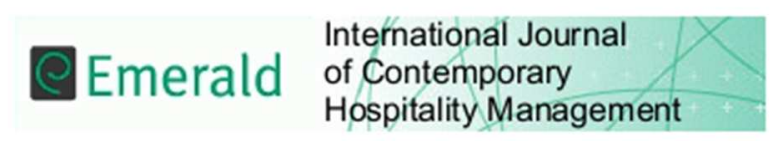

\title{
Corporate governance and performance of Italian gambling SMEs during recession
}

\begin{tabular}{|r|l|}
\hline Journal: & International Journal of Contemporary Hospitality Management \\
\hline Manuscript ID & IJCHM-03-2017-0135.R2 \\
\hline Manuscript Type: & Original Article \\
\hline Keywords: & gambling, SMEs, Performance, Corporate governance, financial crisis \\
\hline \multicolumn{2}{|c}{} \\
\hline
\end{tabular}

SCHOLARONE $^{\text {I" }}$
Manuscripts 
Corporate governance and performance of Italian gambling SMEs during recession

\begin{abstract}
Purpose: This study aims to explore how the economic recession and some corporate governance (CG) provisions can affect the performance of Italian gambling small and mediumsized enterprises (SMEs) across different business segments.

Design/Methodology/approach: This study uses a panel sample of 2,135 observations before and during the global financial crisis. Specifically, the roles of ownership, boards of directors, CEO gender, and gambling business segments are investigated in the Italian gambling market.
\end{abstract}

Findings: Ownership concentration has a negative relationship with the performance of foreigner- and financial-owned firms, while boards exert a positive role on performance. Interestingly, the financial crisis does not impact the performance of Italian gambling SMEs and some business segments, such as bingo, perform even better during the crisis.

Research limitations/implications: Further investigations should analyze the role of single games on firm performance. The consumer- and firm-level examinations offer very different perspectives and scholars should be aware of this when investigating the gambling industry.

Practical implications: This study might help both policymakers and other gambling firms, such as casinos, to better understand which appropriate CG model should be adopted and how it can positively influence performance, especially in recessionary times.

Originality/value: This study contributes to studies on hospitality and tourism by focusing on the complementary role of gambling SMEs with respect to casinos. It also increases knowledge on the role of CG in privately owned gambling firms, which thus far has been scantly investigated by scholars.

Keywords: gambling; SMEs; performance; corporate governance; financial crisis.

Paper type Research paper 


\section{Introduction}

Nowadays, gambling plays a relevant role in the overall travel and tourism industry. It has a significant impact on the GDP of many countries around the world (e.g. Li et al., 2010). In this regard, it is commonly argued that the gambling industry does not seem to have been influenced by the global financial crisis and continues to increase its turnover. Indeed, such industries as casino hotels have been regarded as "recession-proof," as gamblers increase their spending in difficult economic times compared with less turbulent times (Mikesell, 1994; Zheng et al., 2013).

However, since the revenues of these industries are mostly related to people's discretionary consumption (Youn and $\mathrm{Gu}, 2010$ ), even the gambling industry might be confronted by a crisis. In recession times, casinos have to cope with reduced levels of tourism, and individual firms — especially small and medium enterprises (SMEs) — might be strongly and negatively affected by the economic crisis. Therefore, preventing their failure is becoming a prominent issue.

While a growing number of gambling firms are experiencing economic difficulties, very few studies have investigated whether and how gambling activities are influenced by the economic crisis (Cantor and Rosentraub, 2012; Horváth and Paap, 2012). In addition, many studies and reports are focused on either industry-level analysis of economic performance or consumer-level analysis of expenditure, by considering gamblers' behavior and how changes in income due to recession affect their gaming expenditure (e.g. Olason et al., 2015). Only a few studies undertake firm-level investigations, and those that do focus mainly on listed companies, while not much attention has been paid to the large number of unlisted firms comprising the gambling industry. In addition, gambling firms' performance mainly has been investigated in the North America casino context, as constituents of the travel and tourism industry (Jeon and Hyun, 2013). However, casinos are only one type of a number of players 
in the gambling industry. Within the gambling sector, much less attention has been paid to the large number of gambling firms other than casinos, such as bingo operators and licensed betting offices (LBOs). Like casinos, smaller gambling firms also can attract tourists, while offering residents a set of amenities. Given the crisis that has hit casinos, gambling SMEs might revitalize local economies and deter people from travelling abroad only for gaming services. All of these factors call for understanding how gambling SMEs cope during crisis times.

Nevertheless, the financial crisis should not be considered the only determinant of gambling firms' performance. Indeed, some Italian casinos have produced notable losses even before the beginning of the economic crisis. Therefore, other variables should be considered, such as ownership structure and the role of boards of directors. Indeed, corporate governance $(\mathrm{CG})$ is an important determinant of economic performance. Conflicting empirical findings about the traditional relationship between $\mathrm{CG}$ and firm performance might be because CG provisions are industry specific. Since the industry setting should be considered when assessing a particular client's governance mechanisms (Beasley et al., 2000), it becomes critical to explore this relationship in the gambling industry, which is a neglected but hugely relevant industry.

This study investigates the Italian gambling market through a panel sample of 355 SMEs, in order to analyze the extent to which different types of ownership and other governance mechanisms might explain gambling firms' performance before the economic crisis (20052008), during the crisis (2009-2012), and across different gambling business segments. This particular setting represented by Italian gambling SMEs can provide new inferences about the relationship between $\mathrm{CG}$ and financial performance, since $\mathrm{CG}$ might show unexpected dynamics in SMEs as well as in a strongly competitive, intangible, technology-intensive, risky, and opaque industry, such as gambling. 
Therefore, by analyzing this poorly studied industry, our work adds to the sparse body of knowledge on the hospitality industry. In particular, while the majority of previous studies focus on a single casino or closely clustered group of casinos on particular states, this study provides new evidence on the complementary role of privately owned gambling SMEs with respect to the four Italian casinos, thereby providing a good opportunity to improve the external validity of previous results.

\section{Literature review and hypothesis development}

\subsection{Related literature and motivation for this study}

The hospitality industry has been found to have different structural characteristics from other industries, in terms of higher investment and financing (e.g. Upneja and Dalbor, 2001; Kizildag, 2015). As Singal (2015) states, “The formal identification and recognition of these differences provides justification for using the hospitality and tourism industry as a context for testing business theories and can explain differences in decision-making and firm outcomes" (p. 116). In particular, the hospitality and tourism industry's own academic specialties open up opportunities for studying governance structures in this industry (Keiser, 2002), given that the different types of behavior of hospitality firms might be attributable in part to agency problems and CG structures (Oak and Iyengar, 2009).

Recent research of CG issues in the tourism and hospitality industry shows interesting results in terms of differences between this industry and other industries, thereby confirming the notion that CG plays a different role in the hospitality industry (e.g. Moon and Sharma, 2014). For example, hospitality firms have weak shareholder rights (Altin et al., 2016), are more likely to experience agency problems, and have lower governance control mechanisms (Oak and Iyengar, 2009; Guillet and Mattila, 2010). Furthermore, CG has been found to 
differ even within the hospitality industry, that is, across its main segments, such as hotels, restaurants, and casinos (Guillet and Mattila, 2010).

Notwithstanding the increased attention to CG in the hospitality and tourism industry, the relationship between $\mathrm{CG}$ and firm performance in this industry remains under-researched (e.g. Keiser, 2002; Al-Najjar, 2014; Wang, 2015; Yeh and Trejos, 2015), and mainly focused on the hotel or restaurant segments (e.g. Madanoglu and Karadag, 2016), while investigations on casinos involve only limited aspects of CG. No study has yet considered the role of CG as a determinant of gambling SMEs' performance, especially during a recession. This study considers these two phenomena might be interrelated. Indeed, the fact that the 2008 recession is still affecting several countries might be explained by CG failures and weaknesses (Kirkpatrick, 2009). Since CG deals essentially with agency problems, a crisis context, in turn, might increase the relevance of CG procedures, and in particular, the monitoring role of controlling shareholders, because of higher expected managerial agency costs (Roe, 2003). Therefore, stemming from the proposition that governance structures might be industry specific, this study relies on the notion of a disaggregated analysis of industries and their segments, and focuses on the role of CG in the gambling segment.

\subsection{Hypothesis development}

This study follows the OECD view, in which CG is regarded as having a system of rules regarding ownership structure and companies' boards of directors (OECD, 2004). In developing the hypotheses, this study focuses on both traditional agency theory (Jensen and Meckling, 1976) and upper echelon theory (Hambrick and Mason, 1984). The implication for $\mathrm{CG}$ is that adequate monitoring or control mechanisms need to be established to reduce agency costs that occur when management pursues its own interests at the expense of shareholders' interests and thus, of profit maximization. In the following section, this study 
analyzes the impact on gambling SMEs' performance of three main determinants: 1) ownership concentration and type, board size, and CEO gender, 2) the gambling business segment, and 3) the role of the financial crisis.

\subsubsection{Ownership concentration, type, and SMEs performance}

Only a minor number of studies have investigated the impact of ownership concentration on accounting performance of private firms. In most EU civil law countries, and especially in Italy, private firms are characterized by very high ownership concentration, the presence of family ownership, and lower shareholder protection compared to common law countries. Consequently, there is a higher probability of expropriation of minority shareholders, which gives greater private control benefits to majority shareholders (La Porta et al., 2002), and this leads to the general concept of a negative relationship between ownership concentration and non-listed firm profitability. However, the hospitality industry might be different. For example, Yeh and Trejos (2015) find that the presence of large shareholders has a significant influence on tourism firms' return on assets (ROA).

Moreover, since ownership structure might involve different types of owners, this study explores the influence of the type of shareholders on firm performance. Ownership type is related to firm performance. For example, Tsai and Gu (2007) explore the US casino industry during 1999-2003 and find that institutional ownership was a significant and positive determinant of casino firm performance. This study distinguishes the following five ownership identities — insider, family, foreigner, individual, and financial owners - as discussed in the following subsections.

Insider-owned firms. Agency theory predicts that high levels of insider ownership (i.e. executive directors) mitigate conflict of interests between managers and other shareholders, 
thereby strengthening their alignment (Jensen and Meckling, 1976). In the hospitality industry, Guetat et al. (2015) find improvements in the firm efficiency of Tunisian hotels depending on managerial ownership, so supporting the hypothesis of the convergence of interests between manager and shareholders predicted by the agency theory. However, this hypothesis contrasts with the hypothesis of the entrenchment effect, that is, managers feel themselves more protected from potential takeovers. In this case, the entrenchment effect might produce a negative relationship between firm performance and insider ownership (Morck et al., 1988). Chen et al. (2012) argue there is a high probability of differences in insider managerial ownership in various hospitality industries and they find evidence that, after an optimal point, insider ownership causes performance of Taiwanese tourist hotels to deteriorate significantly, supporting the entrenchment hypothesis. Since, in the case of SMEs, it has been found that higher insider-ownership concentration (i.e. more than $68 \%$ ) is associated with lower performance (Keasey et al., 1994), and the entrenchment effect is more likely to occur when the investment is riskier, such as in gambling firms, this study posits the following hypothesis.

H1a. The extent of insider ownership is negatively associated with Italian gambling SMEs' economic performance.

Family-owned firms. Certain differences seem to exist between family- and non-familyowned tourism SMEs (Hallak et al., 2014). Indeed, the "family effect" leads family firms to balance the pursuit of family goals and business goals. For example, Andersson et al. (2002) examine tourism family firms in Australia, Canada, and Sweden and find that family owners used the business as a way to support the livelihood of the family. Since firm performance is related to risk and gambling firms can be considered riskier, the need to preserve family assets and to transfer business to the next generation might constrain the risk taking of family 
businesses and extract more private control benefits at the expense of minority shareholders. Thus, this study posits as follows.

$H 1 b$. There is a negative association between the degree of family ownership and Italian gambling SMEs' economic performance.

Foreigner-owned firms. Generally, foreign ownership positively affects monitoring managerial entrenchment while reducing agency costs (Bekaert and Harvey, 2000, etc.). In addition, foreign owners might bring and foster greater knowledge, experience, and capabilities with regard to international markets (e.g. Fernández and Nieto, 2006). Moreover, since foreign owners often are controlled by parent firms, they could benefit from the parents' support if they belong to a strategic group. For example, Assaf et al. (2013) find that Slovenian casinos belonging to a group perform better than those operating individually do. Pine and Phillips (2005) find that better performance occurs in hotels that have foreign ownership connections. $\mathrm{Gu}$ (2002a) finds that diversifying into other countries helps casinos increase revenue and stabilize their operations. Indeed, while some European countries are characterized by reduced market competitiveness (Gu, 2002b), others, such as Italy, warn of market saturation signals that favor international diversification strategies. In addition, foreign investors might be attracted by potential higher financial returns offered by the gambling market. By having licenses in their country of origin, foreign gambling firms are also licensed to operate in Italy (thus, saving commercial brokerage costs). This study posits as follows.

H1c. The extent of foreign ownership is positively associated with Italian gambling SMEs' economic performance. 
Individual-owned firms. Individual ownership refers to investments by private individuals.

Although the literature on individual-owned firms is scant (no academic research that connects owner investments with SME performance is found), this study considers that the behavior of firms owned by individuals can be associated, to some extent, with family-owned firms' behavior. Individuals are mainly motivated by profit maximization, especially when their investments concern controversial industries, such as gambling. For example, Graham and Kumar (2006) stress that investors aim to achieve dividend income. In addition, individual investors show limits to information processing in relation to their limited portfolio size and risk capacity, so that agency costs are higher. Thus, this study posits as follows.

H1d. The extent of individual ownership is negatively associated with Italian gambling SMEs' economic performance.

Financial-owned firms. Financial institutions (banks, investment firms, and pension funds) invest in other firms in order to improve their financial performance. In the hospitality industry, institutional ownership has been found to be positively related to the performance of US publicly traded casinos (Tsai and Gu, 2007). However, the extent to which institutional investors benefit SMEs has not been explored extensively in the literature. In SMEs, institutional owners might not provide much benefit in terms of reduced agency costs. Furthermore, institutional owners might be more conservative about financing entrepreneurial opportunities that arise in a firm's local environment, thereby constraining firm profitability. Finally, institutional owners can also impose additional reporting requirements, which would add costs to SMEs (Randøy and Goel, 2003). Therefore, this study posits the following hypothesis.

H1e. The extent of ownership by financial institutions is negatively associated with Italian gambling SMEs' economic performance. 


\subsubsection{Board of directors, CEO gender, and SMEs performance}

Board size. In the hospitality context, the relationship between board size and firm performance is more likely to appear different because of the industry's unique financial characteristics (Moon and Sharma, 2014). Findings in hotel and restaurant segments are mixed, with larger boards found to enhance firm profitability (Al-Najjar, 2014), have a negative impact (Yeh and Trejos, 2015), and no significance (Guetat et al., 2015). However, those studies investigate only publicly listed tourism firms, while the general evidence on SMEs is less clear (Bennedsen et al., 2008). O’Connell and Cramer (2010) find strong evidence that the relationship between performance and board size is significantly less negative for smaller firms. Indeed, larger boards could bring more experience, knowledge, and support (Dalton et al., 1999). In addition, the upper echelons theory (the larger the board is, the greater is its diversity) suggests that board diversity might be an important factor in explaining organizational outcomes. This might be especially true in complex environments and technology-intensive industries, such as gambling. Therefore, this study posits as follows.

$H 2 a$. In Italian gambling SMEs, board size is positively related to firm economic performance.

CEO gender. CEO servant leadership has been found to positively influence firm performance in the hospitality industry (Huang et al., 2016). Under the upper echelons theory, top managers' demography is assumed to impact on cognitive processes, which in turn reveals strategic outcomes, such as firm performance (Hambrick and Mason, 1984). In particular, gender appears to be a significant demographic determinant of small business performance (Rosa et al., 1996). Previous studies find a positive relationship between the 
presence of a female as CEO and small business performance (Smith et al., 2006; Davis et al., 2010). Although more female CEOs work in the tourism industry than in the manufacturing industry (Kim and Kim, 2011), results in publicly traded tourism firm find no influence of gender diversity on firm performances (Yeh and Trejos, 2015), while Lee et al. (2016) find that CEO gender negatively affects the internationalization of restaurant companies. However, since the environment in which firms operate might affect the risk appetite of women (Adams and Funk, 2012) — and gambling is a competitive and risky industry - the presence of women as CEOs might produce higher performance, because they are thought to be more risk averse than men are (e.g. Charness and Gneezy, 2012; Khan and Vieito, 2013). This study posits the following hypothesis.

$H 2 b$. In Italian gambling SMEs, the presence of a woman CEO is positively related to firm economic performance.

\subsubsection{Gambling business segments and SMEs performance}

EGMs, including both slot machines and videolottery terminals (VLTs), are the most popular and profitable business segment. For example, Jeon and Hyun (2013) find slot machines to be one of the five casino attributes determining baby boomers' satisfaction. The number of EGMs in Italy is very high (about 400,000 in 2011, i.e. 1 for every 150 people), placing Italy in second place in the world after Australia. Indeed, EGMs represent the largest segment of the Italian market, with a $19 \%$ increase in 2010 compared to 2009 , which is contrary to the general global decreases caused by the global financial crisis (Ernst \& Young, 2011).

In addition, differently to common slot machines that accept only coins, VLTs (about 40,000 in Italy), which were once reserved for casinos, operate with high-value bills and allow higher stakes. In 2011, VLTs accounted for 28\% of Italy's total slots revenues, while in 2012 they accounted for more than $40 \%$ of the total. Thus, this study posits as follows. 
H3. Italian gambling SMEs operating with VLTs perform better than SMEs operating in other business segments do.

\subsubsection{Gambling SMEs performance in the 2008 global financial crisis}

The 2008 global financial crisis has affected international tourism as well as gaming-related regional tourism within countries. Before the global financial crisis of 2008 , the lottery market in the EU had steady growth. The compound annual growth rate (CAGR) for the 27 EU countries amounted to $1.22 \%$ in $2006-2008$. When the financial crisis started, the CAGR of lotteries in 2009-2012 was negative at $-0.56 \%$ (European State Lotteries and Toto Association, 2012).

Previous research on gaming consumption and the financial crisis provides mixed findings, thereby demonstrating that establishing causality between financial crisis effects and firm performance is no easy task. While Mikesell (1994) assumes that in periods of economic crisis, people are less risk averse and find it more attractive to play lotteries, Gu (1999) and Raab and Schwer (2003) show a dramatic decline in the propensity to spend on gaming during the Asian financial crisis of 1997-1998. Mao and Gu (2007) and Youn and Gu (2010) find that the casino industry is more recession-proof than the hospitality industry in general. Horváth and Paap (2012) find that only lottery consumption appears to be recessionproof, whereas casino gambling and pari-mutuel wagering expenditure were affected by the economic recession. Similarly, Cantor and Rosentraub (2012) do not find that US casinos perform better than other forms of tourism during the recession. Finally, Olason et al. (2015) find that national economic recessions have differential effects on gambling behavior, with an increase in gambling participation, except for EGMs, which declined significantly after the economic collapse. This study posits the following hypothesis. 
H4. Compared to the period before the financial crisis, Italian gambling SMEs' economic performance decreased during the 2008 financial crisis.

Moreover, previous studies find different results for different games. For example, Horváth and Paap (2012) and Olason et al. (2015) find an increase in lotteries and a decrease in casino-type games, including EGMs, over the recession period. Therefore, by introducing interaction terms, this study explores whether the effect of the financial crisis is different across the types of gambling business segments, as well as across CG mechanisms analyzed, even though no specific directional hypothesis is formulated.

\section{Methodology and results}

\subsection{Research context: Italian gambling SMEs}

Italy is the world's 8th largest economy, the Eurozone's 3rd largest economy, and among the top 10 international tourism income countries (Cook et al., 2010). Besides its relevance to the global economy and its position in the general hospitality and tourism industry, Italy provides a unique setting and is an ideal context for the present study for the following four main reasons: its gambling industry, the economic crisis, the CG scenario, and the strong prevalence of SMEs.

First, in Italy, gambling is a widespread phenomenon. The overall industry contributes about 8 billion euros a year to public finance. The overall volume of gambling business is equivalent to $4 \%$ of Italian GDP. The average per capita expenditure for national games during 2013 amounted to 1,260 euros. According to research published by MarketLine (2014), Italy accounted for $26.2 \%$ of Western Europe's casino and gaming industry value in 2013. This performance is expected to increase, with an anticipated CAGR of $8.7 \%$ for the 5- 
year period of 2012-2017, which is expected to drive the sector to a value of $\$ 32.3$ billion by the end of 2017.

Second, Italy was hit heavily by the global economic crisis, more than other EU member states. In 2008 and 2009, the Italian GDP decreased by $1.2 \%$ and 5.1\%, whereas the 27 countries of the EU had an average GDP increase of $0.5 \%$ and a decrease of $4.3 \%$, respectively. In 2010, Italy's recovery was more modest than other EU countries $(+1.5 \%$ vs. $1.8 \%)(O E C D, 2011)$. In particular, the crisis peaked in seriousness at the end of 2011, when sovereign debt and yields of Italian bonds increased dramatically. Notwithstanding the above figures, the decline in GDP $(-1.9 \%$ in 2013$)$, and the increase in the unemployment rate (this was $12.2 \%$ in 2013), the gross gaming revenues (GGR) of the Italian casino and gaming industry had a CAGR of 2.9\% between 2008 and 2012 (the EU of 0.3\%) (MarketLine, 2013). In particular, Italian gaming revenues increased from $€ 28.5$ billion to $€ 47.5$ billion in the period 2005-2008 ( $+68 \%$ ), and from $€ 54.4$ billion to $€ 87.1$ billion in the crisis period 2009 $2012(+60 \%)$.

Third, in Italy, CG mechanisms often do not adequately protect minor investors. Italy is the favorite example in the literature of a country in which controlling owners exploit minority shareholders (e.g. Enriques and Volpin, 2007), especially in unlisted companies. Hence, such a civil law country is a good context for investigating how CG performs compared to common law countries (e.g. the UK or US).

Finally, $99.9 \%$ of the firms in Italy are SMEs, which are defined as employing fewer than 250 people (OECD, 2006). This is also the case for the structure of Italian gambling firms, which are characterized by the presence of four large casinos, 10 major dealers, and a large number of very small firms. This is consistent with casino industries in EU countries, which are quite small, especially compared to US casinos (Eadington, 2011). 


\subsection{Sample construction and data collection}

A sample of unlisted Italian gambling firms was extracted from AIDA (Bureau van Dijk), a database containing accounting and governance data for a large number of Italian companies. At the time of the data collection (July 2015), 427 Italian firms belonged to division 92 (Gambling and betting activities) of the NACE Rev. 2 industry classification. After excluding a number of firms and time-observations for different reasons, the final sample includes 355 firms across 8 years, which is an unbalanced sample of 2,135 observations.

\subsection{Econometric model and variable description}

The general econometric model adopted for testing our hypotheses is:

$$
\begin{aligned}
& \text { PERFOR }_{\mathrm{it}+1}=\beta_{0}+\beta_{1} \sum_{\mathrm{X}=1}^{5} \mathrm{OWN}_{\mathrm{iX}}+\beta_{2} \text { BOARD }_{\mathrm{i}}+\beta_{3} \mathrm{GENDER}_{\mathrm{i}}+\beta_{4} \sum_{\mathrm{X}=1}^{3} \mathrm{SEGMENT}_{\mathrm{iX}}+\beta_{5} \mathrm{CRISIS}_{\mathrm{i}} \\
& +\beta_{6} \mathrm{SIZE}_{\mathrm{it}}+\beta_{7} \mathrm{LEV}_{\mathrm{it}}+\beta_{8} \mathrm{AGE}_{\mathrm{it}}+\beta_{9} \mathrm{ONLINE}_{\mathrm{i}}+\beta_{10} \sum_{\mathrm{X}=1}^{2} \mathrm{REGION}_{\mathrm{iX}}+ \\
& \beta_{11} \sum_{\mathrm{X}=1}^{5} \mathrm{OWN}_{\mathrm{iX}} * \mathrm{CRISIS}_{\mathrm{i}}+\beta_{12} \text { BOARD }_{\mathrm{i}}{ }^{*} \text { CRISIS }_{\mathrm{i}}+\beta_{13} \text { GENDER }_{\mathrm{i}} * \mathrm{CRISIS}_{\mathrm{i}}+ \\
& \beta_{14} \sum_{\mathrm{X}=1}^{3} \mathrm{SEGMENT}_{\mathrm{iX}}{ }^{*} \mathrm{CRISIS}_{\mathrm{i}}+\varepsilon_{\mathrm{it}}
\end{aligned}
$$

where:

PERFOR: 1-year leading firm performance proxied by the profitability ratios return on equity (ROE) and ROA;

¿OWN: a set of five variables proxying for ownership, that is, the percentage of shares owned by the ultimate largest shareholder (insider, family, foreign, individual, and financial institution owners;

BOARD: total number of board members;

GENDER: dummy variable proxying for the CEO's gender; it takes a value of 1 if the CEO is a female, and 0 otherwise;

¿SEGMENT: a set of three dummy variables proxying for four business segments, that is, bingo, videolottery, and other (LBOs is the reference category); 
CRISIS: dummy variable proxying for the economic crisis; it takes a value of 1 for the years 2009-2012, and 0 otherwise;

SIZE: firm size proxied by the natural logarithm of total assets;

LEV: leverage proxied by the debt/equity ratio;

AGE: firm age measured by the number of years the firm has been in existence;

ONLINE: dummy variable proxying for remote games; it takes a value of 1 if the firm is authorized to provide online games, and 0 otherwise;

¿REGION: a set of two dummy variables proxying for three Italian regional areas, that is, South and Central (North Italy is the reference category).

This study includes SIZE, LEV, AGE, ONLINE, and REGION as control variables that might affect gambling firms' performance.

\subsection{Descriptive and univariate statistics}

Table 1 provides a breakdown of the sample's characteristics across business segments. Our sample is composed mainly of LBOs. Interestingly, VLTs show larger size than other segments, probably because they do not operate online and thus, they need a greater amount of tangible assets. In addition, VLTs are younger (about 5 years) than other segments, thereby confirming the recent explosion of this gambling segment. Compared to previous studies in US casinos finding an average leverage of 53\% for the 1999-2003 period (Tsai and Gu, 2007), our sample shows a very low level of leverage (about 12\%). Ownership is on average highly concentrated, with family firms owning $79 \%$ of the shares in Italian gambling firms, foreign firms $95 \%$, insiders $71 \%$, individuals $68 \%$, and financial firms $100 \%$. With regard to the board of directors, the average size is about three. A strong presence of male ownermanagers is found. 
As shown in Panel A of Table 2, families and insiders typically control gambling firms, while equity control by financial institutions is far less common, confirming previous analyses of the Italian ownership structure (e.g. Faccio and Lang, 2002). Panel A shows statistically significant differences for the means of main independent and control variables on performance. Both proxies used, ROE and ROA, are statistically different among the ownership types as well as business segments. Family firms perform better than other firms do (e.g. they show an ROE that is, on average, twice that of foreigner-owned firms), while financial-owned firms show negative performances. As for business segment, LBOs (the most common category of activity) together with the residual category ("others") underperform compared to bingo and VLTs. In general, these preliminary statistics confirm that it is relevant to consider both ownership and business segment type when analyzing gambling firm performance.

Panel B of Table 2 shows that online firms outperform firms that are not online, although this difference is significant only for ROA. For the crisis period, since both performance proxies show approximately the same values in the years preceding the financial crisis and during the crisis, it might be concluded that the economic recession does not seem to impact on the performance of gambling firms. Finally, firms located in southern regions of Italy, which are also the poorest, are those with higher performance, thereby supporting the idea of an inverse relationship between socioeconomic position and gambling consumption (e.g. Beckert and Lutter, 2013).

\section{INSERT TABLE 2 ABOUT HERE}

Table 3 shows the mean and median, one-way analysis of variance (ANOVA), and test for the trends of profitability ratios by year. Both performance proxies show highest values for 2006 and 2011, and a drastic reduction in 2012. However, since a high difference exists between the mean and median $-15 \%$ and $7 \%$ for $R O E$ during the $2005-2012$ period - this 
study first performed a one-way ANOVA, showing significant differences of performance by year, thereby partially contrasting prior results on performance before and during the financial crisis. Then, this study performed a non-parametric Cuzick test for trends across the years and this test is not significant, although a follow-up using both the t-test and the MannWhitney test confirmed statistically significant differences for 2006 and 2011 compared to the earlier and later years for both performance measures. The higher performance for 2006 is undoubtedly related to the deregulation law (the so-called Bersani Decree No. 223 of August 2006), which opened the Italian gambling market to foreign dealers and introduced the possibility of playing instant lotteries online. This relevant change has led to the allocation of 158 new licenses, equivalent to 13,686 sales points. Similarly, in March 2011, Italian licensees began to offer online poker and added online casino games.

\section{INSERT TABLE 3 ABOUT HERE}

The Pearson correlation matrix (not tabulated for the sake of brevity) of the variables investigated shows both performance proxies to be significantly related to the independent and control variables used. Only CRISIS and some ownership types (INSIDER and INDIVIDUAL) do not seem to be correlated to performance.

\subsection{Multivariate regression results}

Since our data were both cross-sectional and longitudinal, and random effects (RE) were present, this study adopted an RE panel model in the econometric analysis. In fact, since our independent variables of interest ( $O W N, B O A R D$, and $S E G M E N T)$ were time-invariant, fixed effects could not be estimated without dropping these independent variables. To reduce potential endogeneity issues characterizing the relationship between ownership and firm performance, this study introduced timing in our regression models by leading the dependent 
variable from the independent variable. However, by following Tsai and Gu (2007), this study also checked for endogeneity, and simultaneous equation bias was not found.

Table 4 shows the results of random panel regression analysis, using clustered standard errors, with $R O E$ as the dependent variable. Model 1 shows the impact of only control variables on ROE. Variables traditionally affecting performance (SIZE and LEVERAGE) are statistically significant with the expected sign. In addition, SOUTH is significant, thereby showing that firms located in southern Italy have higher performance than others do. Surprisingly, online gambling firms do not show higher performance than firms that are not online. This could be due to the stronger presence of organized crime in online gambling and its ability to manipulate games, thereby reporting less revenue than actually earned.

Models 2 and 3 introduce ownership types as well as board size and CEO gender, respectively. Although not all ownership type variables are statistically significant, all coefficients are negative, thereby confirming the general idea of a negative relationship between ownership concentration and non-listed firm profitability (e.g. Arosa et al., 2010). For example, in the case of insider-owners, for which the mean and median ownership concentration in our sample is more than $70 \%$ (which is exactly equal to the average ultimate control stake of the largest controlling shareholder of $70.71 \%$ found by Faccio and Lang, 2002), the negative sign is in line with previous results showing that after a level of ownership of $68.2 \%$, profitability decreases as directors' ownership increases up to $100 \%$ (Keasey et al., 1994).

There is a statistically significant relationship between performance and foreigner-owned and financial-owned gambling firms, although only financial-owned firms have the expected negative sign, and thus, this study can accept Hle. Therefore, only for financial-owned gambling SMEs can it be inferred that entrenchment effects of insider ownership exist (Morck et al., 1988). Prior research finds institutional ownership of casinos to be positively 
related to performance (Tsai and Gu, 2007), but in a completely different setting, such as US publicly traded casinos.

With regard to the role of the board of directors, this study accepts $H 2 a$, as the larger is the board, the higher is the performance. This result supports the notion that the board of directors plays a monitoring role in the possible opportunistic behavior of management, since the board controls the actions of management and advises it on strategies to be adopted due to the directors' wealth of knowledge. Especially in complex environments and technologyintensive industries, such as gambling, larger boards bring more experience, knowledge, and support (Dalton et al., 1999), as found by Al-Najjar (2014) for listed tourism firms. Since a larger board means greater diversity, this result seems to support the upper echelons theory.

On the contrary, CEO gender does not seem to affect performance (thus, this study rejects $H 2 b$ ), in line with previous studies in the hospitality industry (Yeh and Trejos, 2015). Therefore, although recent findings that CEO leadership positively influences firm performance in the hospitality industry (Huang et al., 2016), some demographic features suggested by the upper echelons theory, such as CEO gender, do not impact gambling firm performance.

Models 4 and 5 introduce variables proxying for the business segment type and the crisis effect, respectively. BINGO and $V L T$ show a higher performance than do other gambling firms, while the variable CRISIS is negative but not statistically significant. However, when interaction terms (Model 6) are included to capture the moderating effect of the crisis on the business segment, bingo shows a synergic effect. Indeed, the interaction term BINGOx CRISIS is significant and positive, and thus, these gambling firms have higher performance during the crisis period. Instead, the interaction term VLT $x$ CRISIS is not significant. In addition, while the interaction specifications of the crisis effect and ownership type are not 


\section{INSERT TABLE 4 ABOUT HERE}

significant, a positive effect of the board on performance can be observed during the crisis period.

This study repeats regression analysis for $R O A$ (not tabulated) instead of $R O E$ and the findings obtained by replacing the dependent variable are very similar. However, in this case, while evidence is found of reduced performance for all gambling firms during the crisis years (thereby supporting H4), VLT has a significant and positive sign, confirming their higher $R O A$ performance compared to other business segments (the interaction term VLT $x$ CRISIS is again not significant). This result, which supports $H 3$, is more relevant if the $V L T$ segment is considered to have higher tangible assets.

\section{Discussion and conclusion}

\subsection{Conclusions}

To cope with the negative impact of the financial crisis on international tourism, the tourism industry needs an accurate estimate of the effect of the crisis on the performance of all gambling firms, both casinos and smaller gaming-related firms. A peculiarity of Italian legislation is that while the legalization and liberalization wave has enabled the dissemination of a huge number of gambling SMEs offering different kinds of games, that process of liberalization did not simultaneously provide the opportunity to establish new casinos. Thus, while the four Italian casinos are increasing the number of amenities they can offer, their viability is also related to the success of other gambling firms, especially in recessionary times.

As the findings in the literature on the relationship between $\mathrm{CG}$ and financial performance have been inconclusive and this relationship has been found to differ among industries, our motivation was to deepen understanding of the association between board, 
ownership structures, and performance in the global financial crisis era, focusing on a sample of unlisted Italian gambling SMEs during 2005-2012. Our results show that ownership concentration of both financial-owned and foreign gambling firms is negatively related to performance, while the board exerts a role in increasing performance in terms of ROE. The financial crisis does not impact the performance of Italian gambling firms in terms of ROE, while a significant relationship is found in terms of ROA. Since this different impact could be related to the proportion of assets across different gambling business segments, this study explores the interaction between these segments and the financial crisis. Interestingly, some business segments, such as bingo, perform even better during the financial crisis years. This result seems consistent with prior research showing that the effects of economic recession vary according to type of games (e.g. Horváth and Paap, 2012; Olason et al., 2015).

\subsection{Theoretical implications}

The notion that industries, such as gambling, outperform during a financial crisis as a result of increased games consumption should to some extent be rejected from a firm-level perspective. Gambling firms' performance does not vary significantly across the 2008-2012 years of the financial crisis compared to the previous period, although some specific business segments show some advantages from the crisis period. Therefore, the consumer and firm levels offer very different perspectives and scholars should be aware of this when they investigate the gambling industry. By integrating agency cost theory and upper echelons theory with the traits of small gambling firms, this study offers evidence for and throws new light on CG advantages in terms of their significance on firm performance.

\subsection{Practical implications}

http://mc.manuscriptcentral.com/ijchm 
The findings of this study can help both investors and managers to gain greater awareness of which CG mechanisms are effective for their gambling firms, by reducing the ownership concentration (especially for financial-owned and foreign-owned firms) and increasing the size of the board of directors. Indeed, the results provide a better understanding of the role of boards of directors in firm performance in the gambling industry. Given that many SMEs are reluctant to appoint outside directors, as this implies a perceived loss of control, expanding the number of board members could be a relevant solution to improve economic performance, especially in recession times.

Since CG is considered an approach to further develop and professionalize tourism organizations and improve management skills, managers of smaller gambling firms especially could benefit from the effective implementation of CG. In addition, a full understanding of the CG determinants of gambling firms' performance might be critical for casinos and their performance. Indeed, the analysis developed in this study might help the existing four Italian casinos, as well as casinos of other countries, to understand which is the most appropriate CG model adopted by their smaller competitors and how it can positively influence performance.

Regulators and policymakers could benefit from the results of this study about how these firms perform during different periods of an economy's cycle, given the relevant contribution that the financial performance of gambling SMEs make to government revenues. While the Italian government depends on the tax revenues of a huge number of gambling SMEs, and these revenues are stable even during periods of negative economic fluctuations, by excluding the establishment of new casinos, the Italian government is implicitly limiting the possibility of increasing gaming-related tourism. However, since the propensity of Italians to spend their income on gaming services is very strong around the world, this policy might reduce outbound gaming-related tourism, or the movement of people abroad for their 
gambling amusement. By ensuring the viability and profitability of a large number of gambling SMEs, the Italian government could both aim to increase the flow of inbound tourists attracted by other gaming services (e.g. bingo) and to limit outbound gaming-related tourism, thereby maintaining the level of gambling expenditure within national boundaries. In this sense, regulators might wish to expand the role of bingo and videolottery, given their higher performance compared to other business segments.

\subsection{Limitations and further research}

This work has some limitations. Some variables, such as ownership concentration, were not observable across time. However, the number of outstanding shares of a firm is usually (almost) fixed, especially in the case of SMEs, and thus, there is no theoretical reason to obtain incorrect conclusions. Another issue concerns variable proxies for business segments (e.g. LBOs, VLTs, and bingo), since these proxies might not capture the real categories of gambling firms and their games supply. Therefore, further investigations should analyze the role of single games on firm performance. Furthermore, since the gambling industry can either promote social wellbeing (through new employment, increased tourism, development of cities, and higher revenue for the State) or destroy the welfare of a country (through additional social costs generated by pathological gamblers, organized crime, and increased poverty), additional research might be required to investigate the links between gaming consumption choices by individuals, and the performance of gambling firms across European countries, paying attention to the huge differences that exist across these countries in terms of national laws and local regulations, consumer habits, and firm typology.

\section{References}


Adams, R.B. and Funk, P. (2012), “Beyond the glass ceiling: Does gender matter?”, Management Science, Vol. 58 No. 2, pp. 219-235.

Al-Najjar, B. (2014), “Corporate governance, tourism growth and firm performance: Evidence from publicly listed tourism firms in five Middle Eastern countries”, Tourism Management, Vol. 42, pp. 342-351.

Altin, M., Kizildag, M. and Ozdemir, O. (2016), “Corporate governance, ownership structure, and credit ratings of hospitality firms", The Journal of Hospitality Financial Management, Vol. 24 No. 1, pp. 5-19.

Andersson, T., Carlsen, J. and Getz, D. (2002), "Family business goals in the tourism and hospitality sector: Case studies and cross-case analysis from Australia, Canada, and Sweden”, Family Business Review, Vol. 15 No. 2, pp. 89-106.

Arosa, B., Iturralde, T. and Maseda, A. (2010), “Ownership structure and firm performance in non-listed firms: Evidence from Spain", Journal of Family Business Strategy, Vol. 1 No. 2, pp. 88-96.

Assaf, A.G., Cvelbar, L.K. and Pahor, M. (2013), "Performance drivers in the casino industry: Evidence from Slovenia”, International Journal of Hospitality Management, Vol. 32, pp. 149-154.

Beasley, M.S., Carcello, J.V., Hermanson, D.R. and Lapides, P.D. (2000), “Fraudulent financial reporting: Consideration of industry traits and corporate governance mechanisms", Accounting Horizons, Vol. 14 No. 4, pp. 441-454.

Beckert, J. and Lutter, M. (2013), "Why the poor play the lottery: Sociological approaches to explaining class-based lottery play”, Sociology, Vol. 47 No. 6, pp. 1152-1170.

Bekaert, G. and Harvey, C.R. (2000), "Foreign speculators and emerging equity markets", The Journal of Finance, Vol. 55 No. 2, pp. 565-613. 
Bennedsen, M., Kongsted, H. and Meisner Nielsen, K. (2008), “The causal effect of board size in the performance of small and medium-sized firms", Journal of Banking and Finance, Vol. 32 No. 6, pp. 1098-1109.

Cantor, M.B. and Rosentraub, M.S., (2012), “Are gaming and sport effective tourism strategies during economic contractions? Evidence from the performance of baseball and casinos during America's great recession”, Journal of Sport and Tourism, Vol. 17 No. 1, pp. 23-42.

Charness, G. and Gneezy, U. (2012), "Strong evidence for gender differences in risk taking”, Journal of Economic Behavior and Organization, Vol. 83 No. 1, pp. 50-58.

Chen, M.H., Hou, C.L. and Lee, S. (2012), “The impact of insider managerial ownership on corporate performance of Taiwanese tourist hotels", International Journal of Hospitality Management, Vol. 31 No. 2, pp. 338-349.

Cook, R.A., Yale, L.J. and Marqua, J.J. (2010), Tourism: The business of travel, Pearson Education, Upper Saddle River, NJ.

Dalton, D.R., Daily, C.M., Johnson, J.L. and Ellstrand, A.E. (1999), "Number of directors and financial performance: A meta-analysis", Academy of Management Journal, Vol. 42 No. 6, pp. 674-686.

Davis, P.S., Babakus, E., Englis, P.D. and Pett, T. (2010), “The influence of CEO gender on market orientation and performance in service small and medium-sized service businesses”, Journal of Small Business Management, Vol. 48 No. 4, pp. 475-496.

Eadington, W.R. (2011), “After the great recession: The future of casino gaming in America and Europe", Economic Affairs, Vol. 31 No. 1, pp. 27-33.

Enriques, L. and Volpin, P. (2007), “Corporate governance reforms in continental Europe”, The Journal of Economic Perspectives, Vol. 21 No. 1, pp. 117-140. 
Ernst \&Young (2011), "Market overview: The 2011 global gaming bulletin”, available at: http://www.ey.com/Publication/vwLUAssets/2011_global_gamingbulletin/\$FILE/2011\% 20Global\%20Gaming\%20Bulletin.pdf (accessed 12 May 2017).

European State Lotteries and Toto Association (2012), “European Lotteries' report on lotteries in the EU and in Europe in 2011", Lausanne, Switzerland.

Faccio, M. and Lang, L.H. (2002), “The ultimate ownership of Western European corporations", Journal of Financial Economics, Vol. 65 No. 3, pp. 365-395.

Fernández, Z. and Nieto, M.J. (2006), "Impact of ownership on the international involvement of SMEs”, Journal of International Business Studies, Vol. 37 No. 3, pp. 340-351.

Graham, J.R. and Kumar, A. (2006), "Do dividend clienteles exist? Evidence on dividend preferences of retail investors", The Journal of Finance, Vol. 61 No. 3, pp. 1305-1336.

Gu, Z. (1999), “The Impact of the Asian financial crisis on Asian gaming activities: An examination of Las Vegas strip casino drops”, Current Issues in Tourism, Vol. 2 No. 4, pp. 354-365.

Gu, Z. (2002a), “Diversify into European markets to enhance revenue: A strategy proposed for the Las Vegas strip and Atlantic City", UNLV Gaming Research and Review Journal, Vol. 6 No. 2, pp. 34-52.

Gu, Z. (2002b), “Performance gaps between US and European casinos: A comparative study", UNLV Gaming Research \& Review Journal, Vol. 6 No. 2, pp. 53-62.

Guetat, H., Jarboui, S. and Boujelbene, Y. (2015), "Evaluation of hotel industry performance and corporate governance: A stochastic frontier analysis”, Tourism Management Perspectives, Vol. 15, pp. 128-136.

Guillet, B.D. and Mattila, A.S. (2010), “A descriptive examination of corporate governance in the hospitality industry", International Journal of Hospitality Management, Vol. 29 No. 4 , pp. $677-684$. 
Hallak, R., Assaker, G. and O’Connor, P. (2014), “Are family and nonfamily tourism businesses different? An examination of the entrepreneurial self-efficacy-entrepreneurial performance relationship", Journal of Hospitality \& Tourism Research, Vol. 38 No. 3, pp. $388-413$.

Hambrick, D.C. and Mason, P.A. (1984), "Upper echelons: The organization as a reflection of its top managers", Academy of Management Review, Vol. 9 No. 2, pp. 193-206.

Horváth, C. and Paap, R. (2012), “The effect of recessions on gambling expenditures”, Journal of Gambling Studies, Vol. 28 No. 4, pp. 703-717.

Huang, J., Li, W., Qiu, C. and Wan, J. (2016), “The impact of CEO servant leadership on firm performance in the hospitality industry", International Journal of Contemporary Hospitality Management, Vol. 28 No. 5, pp. 945-968.

Jensen, M.C. and Meckling, W.H. (1976), “Theory of the firm: Managerial behavior, agency costs and ownership structure", Journal of Financial Economics, Vol. 3 No. 4, pp. 305360.

Jeon, S.M. and Hyun, S.S. (2013), "Examining the influence of casino attributes on baby boomers' satisfaction and loyalty in the casino industry", Current Issues in Tourism, Vol. 16 No. 4, pp. 343-368.

Keasey, K., Short, H. and Watson, R. (1994), “Directors' ownership and the performance of small and medium sized firms in the UK", Small Business Economics, Vol. 6 No. 3, pp. $225-236$.

Keiser, J.D. (2002), "Boards of directors of the hospitality and tourism industries: An exploratory analysis of composition and interlocks", Journal of Hospitality and Tourism Research, Vol. 26 No. 2, pp. 155-174.

Khan, W.A. and Vieito, J.P. (2013), “CEO gender and firm performance”, Journal of Economics and Business, No. 67, pp. 55-66. 
Kim, S. and Kim, W.G. (2011), "Re-examining the determinants of executive compensation in the restaurant industry: a quantile regression approach", Tourism Economics, Vol. 17 No. 5, pp. $1035-1054$.

Kirkpatrick, G. (2009), “The corporate governance lessons from the financial crisis”, OECD Journal: Financial Market Trends, Vol. 2009 No. 1, pp. 61-87.

Kizildag, M. (2015), “Financial leverage phenomenon in hospitality industry sub-sector portfolios”, International Journal of Contemporary Hospitality Management, Vol. 27 No. 8, pp. $1949-1978$.

La Porta, R., Lopez-de-Silanes, F., Shleifer, A. and Vishny, R. (2002), “Investor protection and corporate valuation", Journal of Finance, Vol. 57 No. 3, pp. 1147-1170.

Lee, W.S., Kim, I. and Moon, J. (2016), “Determinants of restaurant internationalization: An upper echelons theory perspective", International Journal of Contemporary Hospitality Management, Vol. 28 No. 12, pp. 2864-2887.

Li, G., Gu, X. and Siu, R.C.S. (2010), “The impacts of gaming expansion on economic growth: A theoretical reconsideration", Journal of Gambling Studies, Vol. 26 No. 2, pp. $269-285$.

Madanoglu, M. and Karadag, E. (2016), “Corporate governance provisions and firm financial performance: The moderating effect of deviation from optimal franchising”, International Journal of Contemporary Hospitality Management, Vol. 28 No. 8, pp. 1805-1822.

Mao, Z. and Gu, Z. (2007), "Risk-adjusted stock performance. A cross-sector analysis of hospitality firms in the recent economic downturn", International Journal of Hospitality and Tourism Administration, Vol. 8 No. 4, pp. 77-98. 
MarketLine (2013), “Casinos \& gaming in Italy”, available at: http://www.reportlinker.com/p0204662-summary/Casinos-Gaming-in-Italy.html (accessed 12 May 2017).

MarketLine (2014), “Casinos and gaming in Western Europe”, available at: http://www.marketresearch.com/MarketLine-v3883/Casinos-Gaming-Western-Europe8645627/ (accessed 11 May 2017).

Mikesell, J.L. (1994), "State lottery sales and economic activity”, National Tax Journal, Vol. 47 No. 1, pp. 165-171.

Moon, J. and Sharma, A. (2014), "The effect of board classification in the restaurant industry", The Journal of Hospitality Financial Management, Vol. 22 No. 1, pp. 32-40.

Morck, R., Shleifer, A. and Vishny, R.W. (1988), “Management ownership and market valuation: An empirical analysis", Journal of Financial Economics, Vol. 20 No. 1-2, pp. 293-315.

Oak, S. and Iyengar, R.J. (2009) "Investigating the differences in corporate governance between hospitality and non hospitality firms", Advances in Hospitality and Leisure, Vol. 5 No. 5, pp. 125-140.

O’Connell, V. and Cramer, N. (2010), “The relationship between firm performance and board characteristics in Ireland”, European Management Journal, Vol. 28 No. 5, 387-399.

OECD (2004), "Principles of corporate governance”, Available at: http://www.oecd.org/corporate/ca/corporategovernanceprinciples/31557724.pdf (accessed 12 January 2017).

OECD (2006), "Structural and demographic business statistics (SDBS) database”, OECD Publishing, Paris.

OECD (2011), "National accounts online database", OECD Publishing, Paris. 
Olason, D.T., Hayer, T., Brosowski, T. and Meyer, G. (2015), "Gambling in the mist of economic crisis: Results from three national prevalence studies from Iceland", Journal of Gambling Studies, Vol. 31 No. 3, pp. 759-774.

Pine, R. and Phillips, P. (2005), "Performance comparisons of hotels in China”, International Journal of Hospitality Management, Vol. 24 No. 1, pp. 57-73.

Raab, C. and Schwer, R.K. (2003), "The short-and long-term impact of the Asian financial crisis on Las Vegas Strip baccarat revenues", International Journal of Hospitality Management, Vol. 22 No. 1, pp. 37-45.

Randøy, T. and Goel, S. (2003), “Ownership structure, founder leadership, and performance in Norwegian SMEs: Implications for financing entrepreneurial opportunities", Journal of Business Venturing, Vol. 18 No. 5, pp. 619-637.

Roe, M.J. (2003), Political determinants of corporate governance: Political context, corporate impact, Oxford University Press, Oxford, UK.

Rosa, P., Carter, S. and Hamilton, D. (1996), “Gender as a determinant of small business performance: Insights from a British study", Small Business Economics, Vol. 8 No. 6, pp. $463-478$.

Singal, M. (2015), "How is the hospitality and tourism industry different? An empirical test of some structural characteristics", International Journal of Hospitality Management, Vol. 47, pp. 116-119.

Smith, N., Smith, V. and Verner, M. (2006), "Do women in top management affect firm performance? A panel study of 2,500 Danish firms”, International Journal of Productivity and Performance Management, Vol. 55 No. 7, pp. 569-593.

Tsai, H. and Gu, Z. (2007), "The relationship between institutional ownership and casino firm performance”, International Journal of Hospitality Management, Vol. 26 No. 3, pp. $517-$ 530. 
Upneja, A. and Dalbor, M.C. (2001), “An examination of capital structure in the restaurant industry", International Journal of Contemporary Hospitality Management, Vol. 13 No. 2, pp. 54-59.

Wang M.-C. (2015), "Value relevance of Tobin's Q and corporate governance for the Taiwanese tourism industry", Journal of Business Ethics, Vol. 130 No. 1, pp. 223-230.

Yeh, C.M. and Trejos, B. (2015), “The influence of governance on tourism firm performance", Current Issues in Tourism, Vol. 18 No. 4, pp. 299-314.

Youn, H. and Gu, Z. (2010), "The impact of the recent recession on US lodging firms: An examination based on ratio analysis", The Journal of Hospitality Financial Management, Vol. 18 No. 2, pp. 15-29.

Zheng, T., Farrish, J., Lee, M.L. and Yu, H. (2013), "Is the gaming industry still recessionproof? A time series with intervention analysis of gaming volume in Iowa", International Journal of Contemporary Hospitality Management, Vol. 25 No. 7, pp. 1135-1152. 
Table 1 -Descriptive statistics (means) by business segment

\begin{tabular}{lccccc}
\hline \multicolumn{5}{c}{ Business segment } \\
\hline No. companies & LBO & Bingo & VLT & Other & All segments \\
No. observations & $197(55.5 \%)$ & $101(28.5 \%)$ & $42(11.8 \%)$ & $15(4.2 \%)$ & 355 \\
Size & $1,15(52.2 \%)$ & $697(32.6 \%)$ & $228(10.7 \%)$ & $95(4.5 \%)$ & 2,135 \\
Leverage & $4,998,209$ & $3,698,176$ & $11,089,887$ & $6,124,031$ & $5,274,430$ \\
Age & 11.83 & 13.2 & 13.78 & 8.26 & 12.32 \\
Online & 13.18 & 7.48 & 4.92 & 10.91 & 10.34 \\
North & .19 & .01 & 0 & .06 & .11 \\
Centre & .34 & .35 & .47 & .40 & .36 \\
South & .27 & .27 & .25 & .22 & .27 \\
Insider & .38 & .38 & .28 & .38 & .37 \\
Family & .73 & .67 & .73 & .79 & .71 \\
Foreign & .77 & .79 & .90 & .87 & .79 \\
Individual & .98 & .89 & .95 & 1 & .95 \\
Financial & .69 & .67 & .58 & .79 & .68 \\
Board & 0 & 1 & 1 & 0 & 1 \\
Gender & 2.46 & 2.95 & 3.33 & 1.91 & 2.69 \\
\hline
\end{tabular}

Table 2 - Statistical differences in means for main independent and control variables on performance

Panel A - One-way Anova of ownership and business segment on performance

\begin{tabular}{lccccccccc}
\hline & \multicolumn{3}{c}{ Ownership } & \multicolumn{4}{c}{ Business Segment } \\
\hline & Insiders & Family & Foreign & Individual & Financial & LBO & Bingo & VLT & Other \\
N=2,135 & 699 & 782 & 297 & 326 & 31 & 1,115 & 697 & 228 & 95 \\
ROE & .15 & .18 & .09 & .15 & -.02 & .12 & .19 & .19 & .11 \\
F-test & & & $4.08^{* *}$ & & & & & & \\
ROA & -.07 & .12 & -.06 & .08 & -.02 & .04 & .11 & .13 & .05 \\
F-test & & & $34.40^{* * *}$ & & & & $20.62 * * *$ &
\end{tabular}

Panel B - One-way Anova and t-test of online, crisis, and region on performance

\begin{tabular}{|c|c|c|c|c|c|c|c|}
\hline & \multicolumn{2}{|c|}{ Online } & \multicolumn{2}{|c|}{ Crisis } & \multicolumn{3}{|c|}{ Region } \\
\hline & $\begin{array}{l}\text { Online } \\
\text { firms }\end{array}$ & $\begin{array}{l}\text { Not-online } \\
\text { firms }\end{array}$ & $\begin{array}{c}\text { Pre-crisis } \\
\text { years }\end{array}$ & $\begin{array}{l}\text { Crisis } \\
\text { years }\end{array}$ & $\begin{array}{l}\text { South and } \\
\text { Islands }\end{array}$ & Centre & North \\
\hline$N=2,135$ & 231 & 1,904 & 866 & 1,269 & 788 & 573 & 774 \\
\hline$R O E$ & .15 & .12 & .15 & .15 & .21 & .11 & .12 \\
\hline F/T-test & \multicolumn{2}{|c|}{1.31} & \multicolumn{2}{|c|}{.12} & & $3.24 * * *$ & \\
\hline$R O A$ & .08 & -.05 & .08 & .07 & .13 & .01 & .06 \\
\hline$F / T$-test & \multicolumn{2}{|c|}{$8.17 * * *$} & & & & $45.61 * * *$ & \\
\hline
\end{tabular}

Significance: ***(.001);**(.01);*(.05). 
Table 3 -Descriptive statistics, one-way Anova, t-test, and test for trend of dependent variables by year

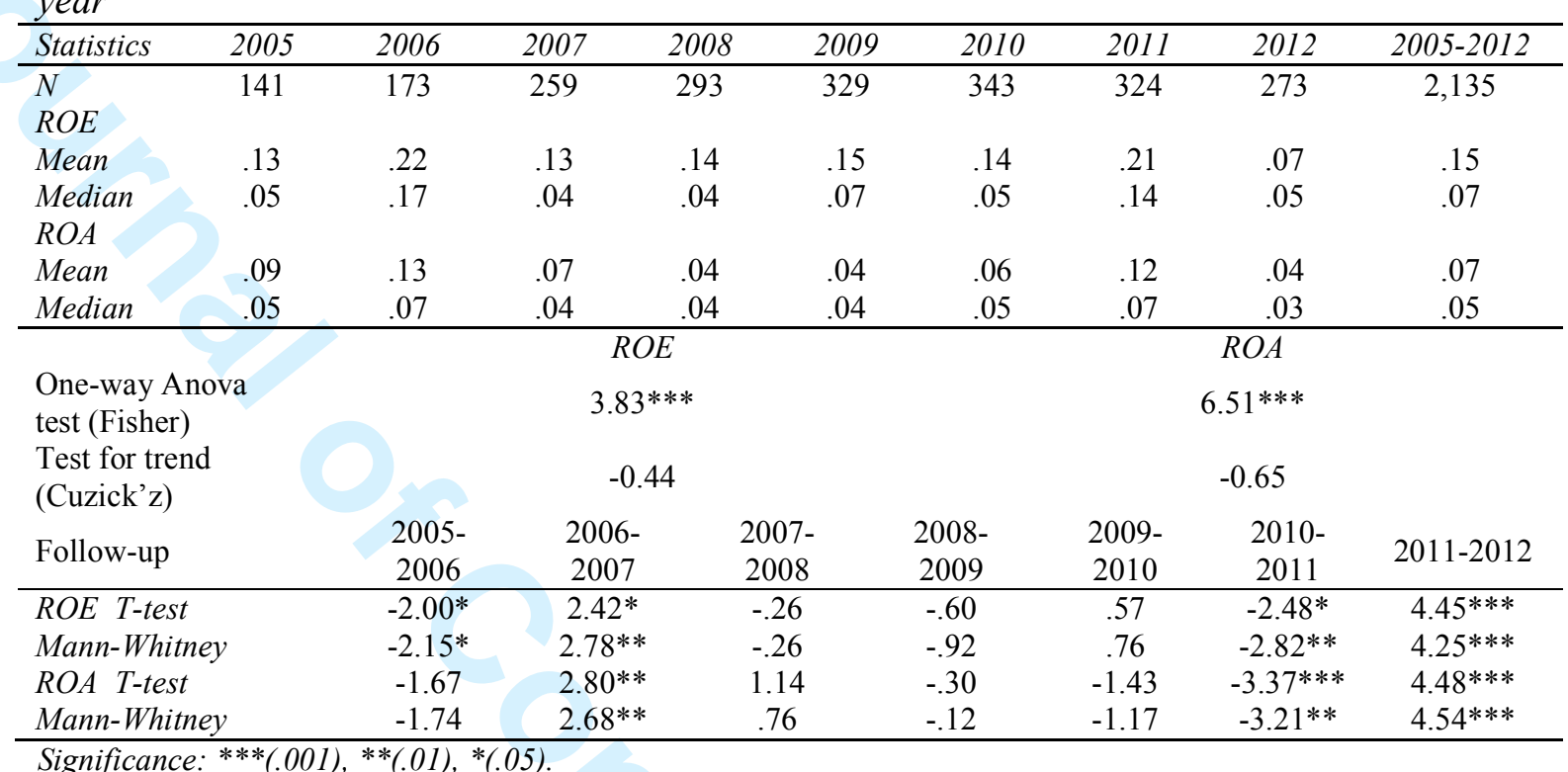


Table 4 - Results of random panel regression with clustered standard errors (Z-statistics in brackets)

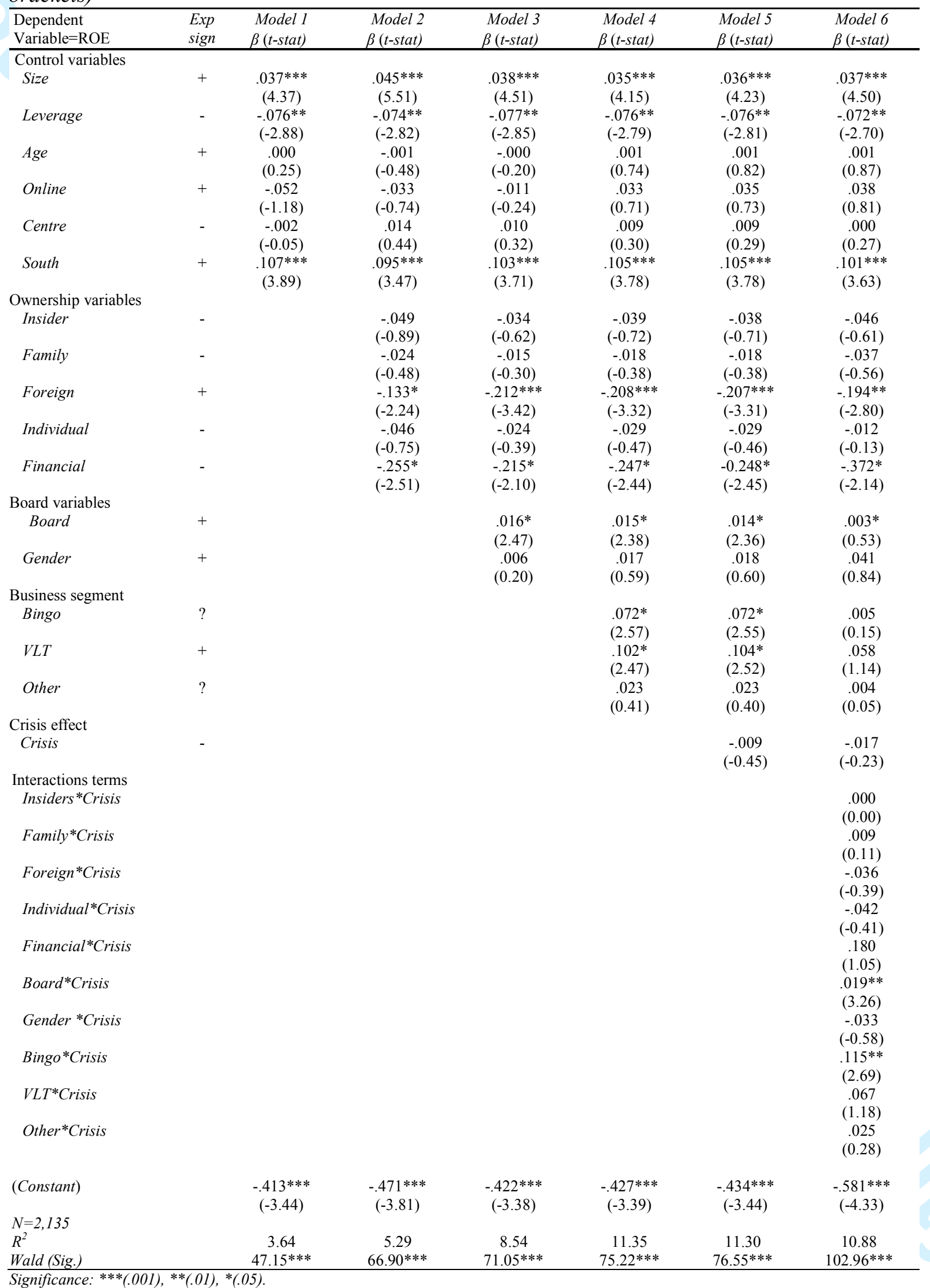

